\title{
PENGARUH MODEL PEMBELAJARAN ICARE BERBANTUAN MASALAH MATEMATIKA TERBUKA TERHADAP KEMAMPUAN PEMECAHAN MASALAH MATEMATIKA SISWA KELAS VIII SMP LABORATORIUM UNDIKSHA SINGARAJA
}

\author{
N. Y. P. Yasa, I. W. P. Astawa, I. G. P. Sudiarta \\ Jurusan Matematika Universitas Pendidikan Ganesha \\ Singaraja, Indonesia \\ e-mail: \{yaditya.permana.yasa, puja.astawa,gussudiarta\}@undiksha.ac.id
}

\begin{abstract}
Abstrak
Penelitian ini bertujuan untuk mengetahui pengaruh model pembelajaran ICARE berbantuan masalah matematika terbuka terhadap kemampuan pemecahan masalah matematika siswa. Jenis penelitian ini adalah eksperimen semu dengan desain penelitian adalah Post Test Only Control Group Design. Populasi penelitian ini adalah seluruh siswa kelas VIII SMP Laboratorium Undiksha Singaraja tahun ajaran 2018/2019 yang berjumlah 98 orang dan terdistribusi ke dalam 4 kelas. Sampel dalam penelitian ini adalah siswa kelas VIII-1 dan VIII-4 yang diambil menggunakkan teknik cluster random sampling. Data kemampuan pemecahan masalah matematika dikumpulkan dengan tes kemampuan pemecahan masalah matematika yang diberikan kepada siswa dalam bentuk tes uraian serta diberikan di akhir penelitian. Data hasil tes kemampuan pemecahan masalah matematika dianalisis menggunakan uji- $t$ satu ekor dengan taraf siginifikansi $5 \%$. Hasil penelitian menunjukkan bahwa $t_{\text {hitun }}=3,3996>t_{\text {tabel }}=2,0117$ sehingga $H_{0}$ ditolak. Ini berarti, kemampuan pemecahan masalah matematika siswa yang dibelajarkan dengan model pembelajaran ICARE berbantuan masalah matematika terbuka lebih baik daripada kemampuan pemecahan masalah matematika siswa yang dibelajarkan dengan model pembelajaran konvensional. Dengan demikian, dapat disimpulkan bahwa terdapat pengaruh model pembelajaran ICARE berbantuan masalah matematika terbuka terhadap kemampuan pemecahan masalah matematika siswa.

Kata kunci: model pembelajaran ICARE, masalah matematika terbuka, pemecahan masalah matematika
\end{abstract}

\begin{abstract}
This study aims to determine the effect of ICARE learning model supported by openended problems to students' mathematical problem solving abilities. The type of this study was a quasi-experiment by using posttest only control group design. The population of this study is all students of class VIII SMP Laboratorium Undiksha Singaraja in the academic year of 2018/2019 with the quantity of 98 and it was distributed in four classes. The students of class VIII-1 and VIII-4 as samples were obtained by using cluster random sampling technique. Data of mathematical problem solving abilities was collected through test of mathematical problem solving abilities given to in the form of essay test and given at the end of study. The Data from test results of mathematical problem solving ability were analyzed using one-tailed t-test with a significance level of $5 \%$. The result showed $t_{\text {hitung }}=3,3996>t_{\text {tabel }}=2,0117$, that make the $H_{0}$ was rejected. This means that the mathematical problem solving abilities who are taught by ICARE learning model supported by open-ended problems are better than students' mathematical problem solving abilities taught by conventional learning model, so it can be conclude that there is an effect of ICARE learning model supported by open-ended problems to students' mathematical problem solving abilities.

Keywords: ICARE learning model, open-ended problem, mathematical problem solving
\end{abstract}


Dalam sistem pendidikan nasional, matematika merupakan mata pelajaran yang sudah tidak asing lagi, karena sudah diberikan mulai dari tingkat dasar, menengah, sampai di perguruan tinggi. Matematika memiliki tujuan dalam pembelajarannya antara lain agar siswa memahami konsep-konsep matematika, menjelaskan keterkaitan antar konsep, mengaplikasikan konsep secara luwes, akurat, efisien, dan tepat serta memiliki sikap menghargai kegunaan matematika dalam kehidupan sehari-hari, yaitu memiliki rasa ingin tahu atau kritis, perhatian, dan memiliki rasa percaya diri dalam pemecahan masalah (Depdiknas, 2006). Berdasarkan tujuan-tujuan ini selayaknya pembelajaran yang dilakukan di sekolah harus mengintegrasikan keterampilan pemecahan masalah yang dapat direalisasikan dengan pengunaan model pembelajaran, metode, strategi maupun bantuan-bantuan pendukung seperti media pembelajaran ataupun sarana lainnya.

Pemecahan masalah dalam matematika pada dasarnya bertujuan untuk membantu siswa dalam mengembangkan pengetahuan serta keterampilan yang dimilikinya. Maulana (2008) menyatakan "pemecahan masalah akan mendorong siswa untuk berpikir kritis dalam memandang setiap permasalahan, kemudian mencoba menemukan jawaban secara kreatif". Parwati (2012:66) menyatakan bahwa "kemampuan pemecahan masalah sangat penting dimiliki oleh siswa sejak dini karena siswa bisa mengaitkan materi matematika yang dipelajari dengan manfaatnya dalam kehidupan sehari-hari mereka". Selain itu, kemampuan pemecahan masalah merupakan salah satu kemampuan yang diharapkan dapat diperoleh melalui bidang pendidikan. Melalui pendidikan formal di sekolah tentunya diharapkan siswa dapat meningkatkan kemampuan pemecahan masalah matematika secara maksimal.

Meskipun pemecahan masalah merupakan aspek yang penting, namun pada kenyataannya kebanyakan siswa masih lemah dalam hal memecahkan masalah matematika. Kelemaham kemampuan pemecahan masalah siswa dapat dilihat dari hasil tes PISA (Program for International Student Assesment). Hasil studi PISA (Program for International Student Assesment) tahun 2015 yang menunjukkan Indonesia yang menduduki peringkat 69 dari 76 negara dengan skor rata-rata yaitu 386 sedangkan skor ratarata Internasional PISA adalah 500 (OECD, 2018). Salah satu faktor yang menjadi penyebab dari rendahnya skor rata-rata matematika siswa Indonesia dalam PISA yaitu lemahnya kemampuan pemecahan masalah soal non-routine atau level tinggi. Soal yang diujikan dalam PISA terdiri atas 6 level (level 1 terendah dan level 6 tertinggi) dan soal-soal yang diujikan merupakan soal kontekstual, permasalahannya diambil dari dunia nyata. Sedangkan siswa di Indonesia hanya terbiasa dengan soal-soal rutin pada level 1 dan level 2 . Mengingat begitu pentingnya kemampuan pemecahan masalah dalam pembelajaran bagi peningkatan kualitas sumber daya manusia, maka pemerintah telah melakukan berbagai upaya guna meningkatkan mutu pembelajaran yang diharapkan bermuara pada meningkatnya mutu pendidikan. Berbagai perubahan dan inovasi pembelajaran telah dilakukan oleh pemerintah. Termasuk perubahan kurikulum yaitu Kurikulum 1994 menjadi KBK, KBK menjadi KTSP 2006, dan KTSP menjadi Kurikulum 2013. Akan tetapi faktanya di lapangan, penerapan pembelajaran yang menggunakan Kurikulum 2013 masih belum maksimal. Hal ini dapat terlihat dari beban belajar siswa di sekolah yang tidak sedikit, konten kurikulum perlu pemahaman lebih mendalam, pembelajaran dengan pendekatan saintifik yang perlu dimaksimalkan penerapannya supaya sesuai diterapkan untuk semua pelajaran, dan buku pelajaran yang membutuhkan anggaran negara yang tidak sedikit dalam pembuatannya.

Berdasarkan bukti-bukti di atas, dapat dinyatakan bahwa siswa dalam belajar matematika masih mengalami kesulitan dalam mengembangkan kemampuan pemecahan masalah matematika. Siswa kurang mampu memahami masalah dan merumuskannya. Sejalan dengan pentingnya kemampuan pemecahan masalah, maka pendidik tentu perlu 
mengusahakan agar siswa mencapai hasil yang optimal dalam menguasai keterampilan pemecahan masalah. Salah satu diantaranya adalah melalui pemilihan model pembelajaran yang tepat yang berpusat pada siswa sehingga dapat meningkatkan kemampuan pemecahan masalah matematika siswa. Model pembelajaran merupakan kerangka konseptual yang menggambarkan prosedur sistimatis dan mengorganisasikan pengalaman belajar untuk mencapai tujuan tertentu serta berfungsi sebagai pedoman dalam merencanakan dan melaksanakan pembelajaran (Sudiarta, 2010:13). Salah satu model pembelajaran yang dapat diterapkan untuk meningkatkan kemampuan pemecahan masalah matematika siswa ICARE.

Carni, dkk. (2017) menyatakan bahwa model pembelajaran ICARE memberikan kesempatan kepada siswa untuk mengkonstruksi pengetahuan sendiri dan mengaplikasikan konsep yang diperoleh melalui proses pemecahan masalah matematika. Model pembelajaran ICARE adalah model pembelajaran yang terdiri dari lima tahapan, yaitu: (1) Introduction atau pengenalan; Connection atau hubungan; (3) Application atau penerapan; (4) Reflection atau refleksi; dan (5) Extension atau kegiatan lanjutan. Dengan menerapkan model pembelajaran ICARE, siswa diarahkan untuk aktif mengonstruksi serta mengaitkan pengetahuannya supaya menemukan makna dari permasalahan yang diberikan sehingga memahami apa sebenarnya konsep-konsep kunci pada permasalahan yang diberikan.

Kelebihan dan kefektifan dari penerapan model pembelajaran ICARE efektif pada mata pelajaran matematika dapat ditunjukkan melalui beberapa penelitaian, diantaranya: penelitian oleh Maskur dkk (2012) menemukan bahwa melalui penerapan model pembelajaran ICARE terjadi peningkatan yang signifikan terhadap kemampuan berpikir kreatif siswa. Selain itu, penelitian oleh Rahmatiah (2016) menunjukkan bahwa model pembelajaran ICARE efektif diterapkan untuk meningkatkan hasil belajar matematika siswa.

Penilitian yang sudah pernah dilakukan menyatakan bahwa model pembelajaran ICARE berpengaruh positif terhadap kemampuan pemecahan masalah. Pada langkah Application guru diharuskan mempunyai strategi serta pertanyaan yang dapat membangkitkan kreatifitas siswa. Maryam (2016) menyatakan pada tahap Application, siswa dituntut untuk dapat menerapkan konsepkonsep yang mereka miliki melalui kegiatan pemecahan masalah dengan berbagai cara yang mungkin dan mereka kuasai. Beberapa penelitian terkait dengan model ini belum dapat mengakomodasi keseluruhan faktor yang mempengaruhi kemampuan pemecahan masalah. Sehubung dengan hal tersebut, untuk memaksimalkan penerapan model pembelajaran ICARE terutama pada langkah Application terhadap kemampuan pemecahan masalah matematika, maka sepatutnya model ini dibantu dengan masalah matematika terbuka.

Masalah matematika terbuka merupakan masalah matematika yang dirumuskan sedemikian rupa, sehingga memiliki banyak cara ataupun solusi yang benar dan terdapat banyak cara penyelesaian untuk mencari solusi tersebut (Sudiarta, 2008). Penggunaan masalah terbuka dalam proses pembelajaran membuat siswa lebih terlatih dalam menyelesaikan permasalahan matematika. Selain itu, pemberian latihan berupa masalah matematika terbuka diharapkan mampu membuat siswa lebih menghargai proses dibandingkan hasil. Adapun penelitian yang mendukung penerapan masalah matematika terbuka adalah penelitian oleh Kumarayasa (2016) yang menyatakan bahwa pembelajaran generatif yang dibantu dengan masalah matematika terbuka efektif untuk meningkatkan kemampuan pemecahan masalah matematika siswa.

Model pembelajaran ICARE berbantuan masalah matematika terbuka merupakan pembelajaran dengan sintaks sesuai dengan model ICARE dikolaborasikan dengan masalah matematika terbuka. Dimana tujuannya 
untuk memberikan siswa ruang gerak untuk berpikir kritis dalam memecahkan suatu permasalahan. Siswa yang dihadapkan dengan masalah matematika terbuka, tujuan utamanya bukan untuk mendapatkan jawaban semata, tetapi lebih pada bagaimana cara sampai pada suatu jawaban. Dengan demikian pembelajaran model ICARE berbantuan masalah matematika terbuka yang diterapkan dalam pembelajaran akan saling mendukung dalam tujuannya untuk meningkatkan kemampuan pemecahan masalah.

Berdasarkan uraian yang telah dipaparkan di atas, maka perlu dilakukan suatu kajian secara mendalam untuk mengetahui apakah terdapat pengaruh penerapan model pembelajaran ICARE berbantuan masalah matematika terbuka terhadap kemampuan pemecahan masalah matematika siswa. Dengan demikian, penelitian ini berjudul "Pengaruh Model Pembelajaran ICARE Berbantuan Masalah Matematika Terbuka Terhadap Kemampuan Pemecahan Masalah Matematika Siswa Kelas VIII SMP Laboratorium Undiksha Singaraja".

\section{METODE}

Penelitian ini merupakan penelitian eksperimen semu (quasi experiment), karena tidak seluruh variabelnya diatur dan dikontrol secara ketat. Rancangan penelitian yang digunakan adalah post test only control group design, artinya pada pertemuan terakhir kedua kelompok tersebut akan diberikan tes yang sama (post-test), selanjutnya skor dari post-test tersebut digunakan sebagai pedoman dalam melakukan uji hipotesis.

Populasi dalam penelitian ini adalah seluruh siswa kelas VIII SMP Laboratorium Undiksha Singaraja tahun pelajaran 2018/2019 yang kemampuan akademiknya terdistribusi secara merata ke dalam 4 kelas. Dalam penentuan sampel dipilih dua kelas dengan teknik cluster random sampling yang selanjutnya secara acak dipilih kelas yang menjadi kelompok eksperimen dan kelompok kontrol, diperoleh VIII 1 sebagai kelompok eksperimen yang akan dibelajarkan dengan model pembelajaran ICARE berbantuan masalah matematika terbuka dan kelas VIII 4 sebagai kelompok kontrol yang akan dibelajarkan dengan pembelajaran konvensional.

Terdapat dua jenis variabel yang terlibat dalam penelitian ini, yaitu variabel bebas (independent variable) dan variabel terikat (dependent variable). Variabel bebas dalam penelitian ini adalah model pembelajaran, dimana model pembelajaran ICARE berbantuan masalah matematika terbuka diterapkan pada kelas eksperimen dan model pembelajaran konvensional diterapkan pada kelas kontrol. Variabel terikat dalam penelitian ini adalah kemampuan pemecahan masalah matematika siswa kelas VIII SMP Laboratorium Undiksha Singaraja. Rancangan penelitian ini dapat dilihat pada Tabel 1.

Instrumen yang digunakan dalam penelitian ini berupa tes kemampuan pemecahan masalah matematika yang berbentuk uraian (essay). Kemampuan pemecahan masalah matematika siswa diukur dari kemampuan siswa memahami masalah, membuat rencana penyelesaian, melaksanakan rencana penyelesaian, dan memeriksa kembali pekerjaannya. Instrumen dikatakan baik jika memenuhi dua syarat yaitu valid dan reliabel. Untuk mengetahui validitas dan reliabilitas dari instrumen maka harus dilakukan uji coba instrumen.

Uji coba instrumen penelitian dilakukan untuk mendapatkan gambaran apakah instrumen penelitian berupa tes kemampuan pemecahan masalah matematika siswa layak digunakan sebagai

Tabel 1. Rancangan Penelitian

\begin{tabular}{lcc}
\hline Kelompok & Perlakuan & Post test \\
\hline Eksperimen & $X$ & $Y$ \\
Kontrol & - & $Y$ \\
\hline \multicolumn{3}{c}{ (dikutip dari Zarkasyi, 2015) } \\
Keterangan: \\
$X=$ Perlakuan berupa penerapan model \\
pembelajaran ICARE berbantuan \\
$\quad$ masalah matematika terbuka \\
$Y=$ Hasil Post-test
\end{tabular}

instrumen. Sebelum diberikan kepada siswa yang menjadi sampel penelitian, 
akan dilakukan beberapa uji terhadap instrumen penelitian untuk mendapatkan tes yang baik. Pertama akan dilakukan uji pakar/ahli untuk mengetahui validitas isi instrumen. Validitas isi dilakukan oleh dua orang pakar yang merupakan dosen di Jurusan Matematika Undiksha.

Perhitungan validitas isi dilakukan dengan formula Gregory dan dari hasil perhitungan diperoleh koefisien validitas isi tes kemampuan pemecahan masalah yang akan diujicobakan adalah 1,00 yang berarti tes kemampuan yang akan diujicobakan sangat relevan. Selanjutnya, tes kemampuan pemecahan masalah matematika diuji coba pada kelas VIII A1 SMP N 6 Singaraja pada tanggal 16 April 2019 dengan total soal yang diuji cobakan adalah 6 butir soal dan hasilnya digunakan untuk menghitung validitas dan reliabilitas instrumen tersebut.

Salah satu upaya untuk mencari koefisien validitas instrumen yang berbentuk uraian adalah dengan menggunakan koefisien korelasi productmoment oleh Carl Pearson (Candiasa, 2010b). Berdasarkan hasil analisis validitas tes uji coba diperoleh 6 butir soal valid. Selanjutnya, butir soal yang valid diuji reliabilitasnya. Suharsimi Arikunto (2010) menyatakan bahwa reliabilitas tes mengacu pada tingkat konsistensi hasil pengukuran yang ditunjukkan oleh instrumen tersebut. Untuk menentukan reliabilitas instrumen bentuk essay (uraian) dapat menggunakan rumus Alpha Cronbach (Candiasa, 2010a). Berdasarkan hasil analisis reliabilitas tes, diperoleh koefisien reliabilitasnya adalah 0,7275 . Hasil tersebut menunjukkan bahwa tes uji coba kemampuan pemecahan masalah matematika siswa reliabel dengan reliabilitas tinggi, sehingga soal-soal tersebut layak untuk digunakan. Dari enam butir soal yang valid dan reliabel dipilih lima butir soal yang digunakan sebagai tes kemampuan pemecahan masalah matematika siswa, kelima soal tersebut sudah mencakup keseluruhan materi dan indikator pembelajaran.

Sebelum dapat dilakukan pengujian hipotesis penelitian, data kemampuan pemecahan masalah matematika yang telah diperoleh perlu diuji dengan uji prasyarat, diantaranya uji normalitas dan uji homogenitas varians. Setelah terpenuhi kriteria normal dan varians yang homogen, selanjutnya dapat dilakukan uji hipotesis untuk memperoleh kesimpulan dari penelitian yang telah dilakukan dengan menggunakan uji-t satu ekor.

\section{HASIL DAN PEMBAHASAN}

Rangkuman analisis terhadap skor kemampuan pemecahan masalah matematika siswa pada kelompok eksperimen dan kelompok kontrol dapat dilihat pada Tabel 2. Pengujian normalitas sebaran data pada penelitian ini dilakukan dengan menggunakkan uji Liliefors pada taraf signifikan 5\%. Hasil analisis uji normalitas pada kelompok eksperimen dengan data sebanyak 25 , menunjukkan bahwa nilai $L_{\text {hitung }}$ sebesar 0,0824 dan nilai $L_{\text {tabel }}$ sebesar 0,173. Sedangkan, pada kelompok kontrol dengan data sebanyak 25 , menunjukkan bahwa $L_{\text {hitung }}$ sebesar 0,0845 dan $L_{\text {tabel }}$ sebesar 0,177 . Terlihat bahwa pada kelompok eksperimen maupun kelompok kontrol menunjukkan nilai $L_{\text {hitung }}<L_{\text {tabel }}$. Ini berarti, data kemampuan pemecahan masalah matematika siswa berasal dari populasi yang berdistribusi normal. Analisis data dilanjutkan dengan melakukan pengujian homogenitas varians. Pada penelitian ini, pengujian varians dilakukan dengan menggunakkan uji- $F$ dan diperoleh $F_{\text {hitung }}=$

1,21305. Berdasarkan tabel untuk taraf signifikan $5 \%, d k$ pembilang $=25$ dan $d k$ penyebut $=24$, diperoleh $F_{\text {tabel }}$ $=F_{((0,05),(25,24))}=2,005009$. Karena $F_{\text {hitung }}<F_{\text {tabel }}$, ini berarti data kemampuan

Tabel 2. Rangkuman Analisis terhadap Data Kemampuan Pemecahan Masalah Matematika Siswa

\begin{tabular}{ccc}
\hline \multirow{2}{*}{ Variabel } & \multicolumn{2}{c}{ Post-test } \\
\cline { 2 - 3 } & $\begin{array}{c}\text { Kelompok } \\
\text { Eksperimen }\end{array}$ & $\begin{array}{c}\text { Kelompok } \\
\text { Kontrol }\end{array}$ \\
\hline $\mathrm{N}$ & 25 & 24 \\
Mean & 76,66 & 70,48 \\
Varians & 44,368 & 36,576 \\
$\mathrm{SD}$ & 6,661 & 6,048 \\
\hline
\end{tabular}


pemecahan masalah matematika siswa mempunyai varians yang homogen.

Berdasarkan hasil uji normalitas dan homogenitas varians, diperoleh bahwa sebaran data kemampuan pemecahan masalah matematika siswa pada kelompok eksperimen dan kelompok kontrol berdistribusi normal, serta memiliki varians yang homogen. Selanjutnya dilakukan uji hipotesis dengan menggunakkan uji- $t$ satu ekor pada taraf signifikan $5 \%$. Rangkuman hasil analisis uji-t dapat dilihat pada Tabel 3. Berdasarkan Tabel 3, menunjukkan bahwa $t_{\text {hitung }}>t_{\text {tabel }}$. Ini berarti, kemampuan pemecahan masalah matematika siswa yang dibelajarkan dengan model pembelajaran ICARE berbantuan masalah matematika terbuka lebih baik daripada kemampuan pemecahan masalah matematika siswa yang dibelajarkan dengan model pembelajaran konvensional.

Pada kelas eksperimen diterapkan model pembelajaran ICARE berbantuan masalah matematika terbuka. Pada kelas ini, pembelajaran berpusat pada siswa, dimana pada setiap kegiatan pembelajaran siswa belajar dalam kelompok untuk menyelesaikan permasalahan yang ada pada Lembar Kerja Siswa (LKS). Penerapan model pembelajaran ICARE berbantuan masalah matematika terbuka mendukung siswa dalam meningkatkan kemampuan pemecahan masalah matematika melalui lima tahapan pembelajaran. Tahapan dalam model pembelajaran ICARE, diantaranya: (1) Introduction (pengenalan), (2) Connection (hubungan), (3) Application (penerapan), (4) Reflection (refleksi), dan (5) Extension (kegiatan lanjutan).

Tabel 3. Rangkuman Hasil Uji- $t$

\begin{tabular}{ccc}
\hline \multirow{2}{*}{ Variabel } & \multicolumn{2}{c}{ Post-test } \\
\cline { 2 - 3 } & $\begin{array}{c}\text { Kelompok } \\
\text { Eksperimen }\end{array}$ & $\begin{array}{c}\text { Kelompok } \\
\text { Kontrol }\end{array}$ \\
\hline$N$ & 25 & 24 \\
$d k$ & 47 & 47 \\
$\bar{X}$ & 76,66 & 70,48 \\
$S D$ & 6,661 & 6,048 \\
$t_{\text {hitung }}$ & \multicolumn{2}{c}{3,3996} \\
$t_{\text {tabel }}$ & \multicolumn{2}{c}{2,0117} \\
\hline
\end{tabular}

Berdasarkan hasil pengamatan yang dilakukan peneliti, model pembelajan ICARE berbantuan masalah terbuka dalam proses pembelajaran dapat mengefektifkan proses pemecahan masalah, karena setiap masalah terbuka yang diberikan membuat siswa mempunyai banyak kesempatan dalam menjawab dan bertanya. Hal tersebut sejalan dengan pendapat Japa dkk, (2012:79), menyatakan bahwa secara konseptual, masalah terbuka dalam pembelajaran matematika adalah "masalah atau soal-soal matematika yang dirumuskan sedemikian rupa, sehingga memiliki beberapa solusi bahkan banyak solusi yang benar dan terdapat banyak cara untuk mencari solusi tersebut". Sedangkan dalam pembelajaran yang menggunakan model pembelajaran konvensional, siswa mencatat yang dijelaskan secara langsung oleh guru dan mengerjakan LKS dengan membagi tugas dengan tujuan mempercepat proses pengerjaan. Hal tersebut menyebabkan orientasi siswa dalam belajar menjadi berubah, bukannya untuk memahami atau menguasai materi yang diajarkan melainkan hanya ingin cepat dalam menyelesaikan permasalahan yang ada tanpa memaksimalkan kesempatan berdiskusi yang ada.

Langkah-langkah model pembelajaran ICARE berbantuan masalah matematika terbuka melatih siswa dalam membangun sendiri pemahamannya terhadap apa yang sedang dipelajari dan dapat menanggapi setiap permasalahan yang ada. Pada awal proses pembelajaran guru mengkondisikan siswa pada posisi siap untuk melaksanakan pembelajaran (Introduction), sehingga setiap siswa diharapkan dapat memahami pemaparan ataupun permasalahan matematika yang dimunculkan oleh guru. Pada tahap Connection guru sebagai fasilitator mengantarkan konsep baru melalui pertanyaan-pertanyaan pancingan yang membuat siswa secara aktif dalam menemukan konsep baru dengan menggunakan pemahaman sendiri. Siswa mengkonstruksi pemahaman akan konsepkonsep matematis yang nantinya dapat dipergunakan pada tahap Application. Dari pengamatan peneliti, seringkali siswa 
mengacungkan tangan dan menceritakan kejadian serta pengalaman mereka terkait dengan konsep matematis yang diajarkan. Pembentukan konsep-konsep matematis melalui penerapan model pembelajaran ICARE ini sejalan dengan penelitian yang telah dilakukan Wahyuni (2018) yang menyatakan bahwa model pembelajaran ICARE berpengaruh positif terhadap kemampuan pemahaman konsep matematika siswa. Pemahaman konsep siswa yang baik dapat membantu siswa dalam memahami masalah serta memudahkan siswa dalam memecahkan permasalahan yang diberikan.

Pada tahap Application siswa dituntun dalam melaksanakan langkahlangkah pemecahan masalah melalui permasalahan matematika terbuka. Melalui pemberian masalah matematika terbuka dalam proses pembelajaran dapat menumbuhkan aktivitas siswa serta minat siswa dalam belajar. Pada tahap ini, siswa terlatih untuk mampu memahami, mengomunikasikan ide mereka dalam menyelesaikan permasalahan dan saling bertukar pendapat. Latihan diberikan dengan masalah terbuka dapat membantu mengembangkan kegiatan kreatif dan pola pikir matematika siswa sehingga mampu melatih siswa dalam meningkatkan kemampuan pemecahan masalah. Menyelesaikan masalah yang dilakukan siswa tidak luput dari kesulitan dan kesalahan yang dialami siswa. Adapun dengan pemberian masalah matematika terbuka siswa tidak lagi terpaku pada solusi akhir, melainkan bagaimana cara serta proses matematis dalam menemukan solusi tersebut.

Pada tahap Reflection, siswa saling mengomunikasikan dan menyatakan solusi terkait dengan pemecahan masalah yang didapatkan. Mereka juga memeriksa kembali solusi yang telah dibuat yang dapat membuat siswa lebih paham terkait dengan materi yang telah dipelajari. Pada kelas eksperimen, didapatkan bahwa penggunaan masalah matematika terbuka mengakibatkan, saat presentasi kelompok berlangsung, beberapa siswa tampak aktif untuk mengajukan jawaban yang berbedabeda. Perbedaan pendapat dan hasil jawaban dari masalah terbuka yang diberikan pada masing-masing kelompok menyebabkan diskusi antar kelompok terjadi. Hal tersebut membuat situasi pembelajaran aktif dan melatih siswa dalam mengemukakan pendapatnya. Apabila secara umum kelas mengalami kesulitan maka guru dapat mengajak siswa untuk bersama-sama mencermati kembali langkah-langkah penyelesaian dan solusi akhir yang mereka dapatkan. Dalam hal ini guru dapat melakukan koreksi dan mengarahkan kembali terkait konsep ataupun pemecahan masalah yang keliru. Pada tahap Extension, siswa mengembangkan pengetahuan yang telah didapatkan pada kegiatan pembelajaran terkait dengan pemecahan masalah matematika, hasil dari serangkaian kegiatan ini tentunya berakibat pada berkembangnya kemampuan pemecahan masalah matematika yang dimiliki oleh siswa.

Hasil analisis tes kemampuan pemecahan masalah matematika siswa menunjukkan bahwa siswa yang mengikuti pembelajaran dengan model pembelajaran ICARE berbantuan masalah terbuka lebih baik dibandingkan dengan siswa yang mengikuti pembelajaran konvensional. Hal tersebut dikarenakan dengan menerapkan model pembelajaran ICARE berbantuan masalah terbuka seperti yang dipaparkan diatas siswa terbiasa berdiskusi dalam kelompoknya, menemukan konsep baru, menyelesaikan pertanyaan arahan yang diberikan dengan LKS berisikan masalah terbuka didukung dengan latihan sehingga dapat memantapkan dalam memecahkan masalah matematika siswa.

Secara umum dapat diberikan kesimpulan bahwa penerapan model pembelajaran ICARE berbantuan masalah matematika terbuka memberikan pengaruh positif terhadap kemampuan pemecahan masalah matematika siswa. Hal tersebut juga didukung oelh hasil uji hipotesis yang menunjukkan kemampuan pemecahan masalah matematika siswa yang mengikuti pembelajaran dengan model pembelajaran ICARE berbantuan masalah matematika terbuka lebih baik daripada kemampuan pemecahan masalah matematika siswa yang mengikuti pembelajaran konvensional. Melihat kontribusi positif 
tersebut, diharapkan model pembelajaran ICARE berbantuan masalah matematika terbuka dapat dikembangkan dan diterapkan dalam proses pembelajaran khususnya proses pembelajaran matematika di Indonesia.

\section{SIMPULAN DAN SARAN}

Berdasarkan rumusan masalah, tujuan, hasil analisis, dan pembahasan yang telah diuraikan di depan, dapat disimpulkan bahwa kemampuan pemecahan masalah matematika siswa kelas VIII SMP Laboratorium Undiksha Singaraja yang dibelajarkan dengan model pembelajaran ICARE berbantuan masalah matematika terbuka lebih baik daripada kemampuan pemecahan masalah matematika siswa yang dibelajarkan dengan model pembelajaran konvensional.

Berdasarkan hasil penelitian yang telah dilakukan, peneliti melalui tulisan ini menyampaikan beberapa saran sebagai berikut.

1. Kepada praktisi pendidikan, khususnya pihak-pihak yang terlibat dalam pembelajaran matematika disarankan untuk menggunakan model pembelajaran ICARE berbantuan masalah matematika terbuka sebagai salah satu alternatif pembelajaran di kelas.

2. Penelitian ini dilakukan pada sampel dan materi pembelajaran yang terbatas. Para peneliti lain yang tertarik disarankan untuk melakukan penelitian terhadap model pembelajaran ICARE berbantuan masalah matematika terbuka dengan sampel yang lebih besar dan materi pembelajaran yang lebih luas untuk mengetahui pengaruh penerapan model pembelajaran ini dalam pembelajaran matematika secara lebih mendalam.

\section{DAFTAR PUSTAKA}

Arikunto, S. 2010. Prosedur Penelitian Suatu Pendekatan Praktik. Jakarta: Rineka Cipta
Candiasa, I Made. 2010a. Pengujian Instrumen Penelitian Disertai Aplikasi ITEMAN dan BIGSTEPS. Singaraja: Universitas Pendidikan Ganesha.

2010b. Statistik Univariat dan Bivariat Disertai Aplikasi SPSS. Singaraja: Universitas Pendidikan Ganesha.

Depdiknas. 2006. Standar Kompetensi dan Kompetensi Dasar SMP. Jakarta: Depdiknas

IEA. 2012. TIMSS 2011 International Results in Mathematics. (Online). Tersedia pada:https://timss.bc.edu/timss2011/ downloads/T11_IR_M_Chapter1.pdf

Maskur, A. 2012. Pembelajaran Matematika dengan Strategi ICARE Beracuan Konstruktivisme Untuk Meningkatkan Kemampuan Berpikir Kreatif Materi Dimensi Tiga. Journal of Primary Education, 1(2).

Maulana. 2008. Dasar-dasar Keilmuan Matematika. Subang: Royyan Pres.

OECD. 2018. PISA 2015 Result in Focus what 15-years-olds Know and what They Can Do with What They Know. Tersedia pada https://www.oecd.org/pisa-2015result-in-focus.pdf. (diakses tanggal 01 Desember 2018)

Parwati, N. N. 2012. Pengembangan Perangkat Pembelajaran Matematika Berorientasi Open-ended Problem Solving. Jurnal IImu Pendidikan Universitas Negeri Malang, 18(1).

Sudiarta, I G. P. 2008. Paradigma Baru Pembelajaran Matematika Membangun Kompetensi Berfikir Kritis Melalui Pendekatan OpenEnded. ISBN 978-602-8310-03-1. Singaraja: Undiksha. Edisi Revisi.

Sudiarta, I G. P. 2010. Pengembangan model pembelajaran inovatif. 
Karangasem: Makalah Pelatihan MGMP.

Wahyuni, V. 2018. Pengaruh Model Pembelajaran ICARE Terhadap Pemahaman Konsep Matematika Siswa Kelas VIII Non Unggulan SMP Negeri 3 Sawan. Singaraja. Singaraja: Universitas Pendidikan Ganesha.

Zarkasyi, W. 2015. Penelitian Pendidikan Matematika. Cetakan Kesatu. Bandung: PT Refika Aditama. 